\title{
Synopsis of a new collection of sea spiders (Arthropoda: Pycnogonida) from the Ross Sea, Antarctica
}

\author{
Johanna Fønss Nielsen · Shane Lavery • \\ Anne-Nina Lörz
}

Published online: 15 July 2009

(C) Springer-Verlag 2009

\section{Erratum to: Polar Biol}

DOI 10.1007/s00300-009-0611-8

In the published original article, Table 1, heading site information, the coordinates in the column should be $\mathrm{S}$ and $\mathrm{E}$ instead of $\mathrm{N}$ and $\mathrm{W}$.

The online version of the original article can be found under doi:10.1007/s00300-009-0611-8.

J. F. Nielsen · S. Lavery

School of Biological Sciences,

University of Auckland, Private Bag 92 019,

Auckland 1142, New Zealand

\section{A.-N. Lörz}

Biodiversity and Biosecurity,

National Institute of Water and Atmospheric Research,

Private Bag 14901, Kilbirnie, Wellington, New Zealand

Present Address:

J. F. Nielsen $(\bowtie)$

Institute of Zoology, Zoological Society of London,

Regent's Park, London NW1 4RY, UK

e-mail: johanna.nielsen@ioz.ac.uk 